\title{
Science stars of
}
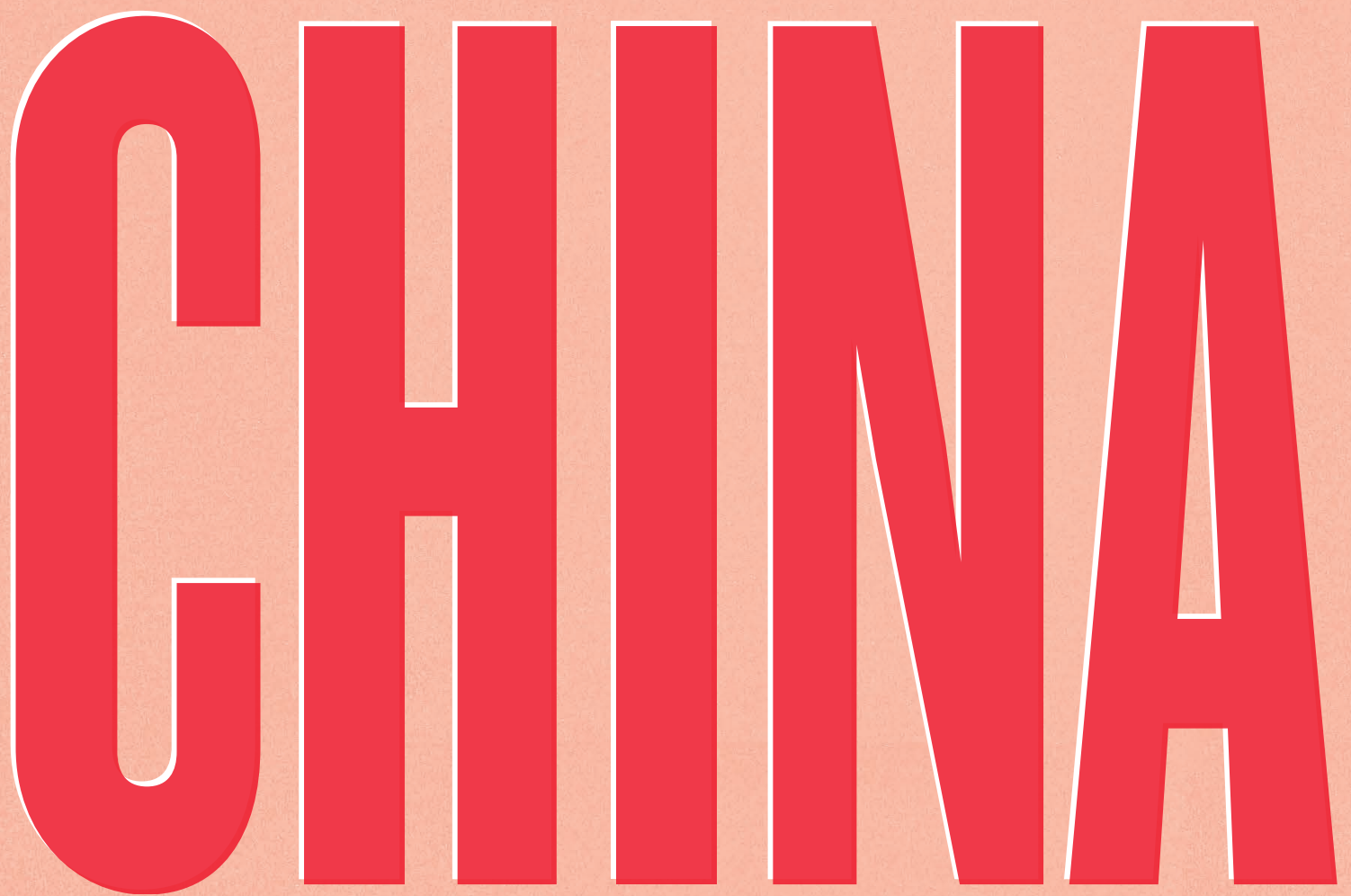

\section{From ancient DNA to} neutrinos and neuroscience, top researchers in China are making big impacts - and raising their country's standing in global science. 


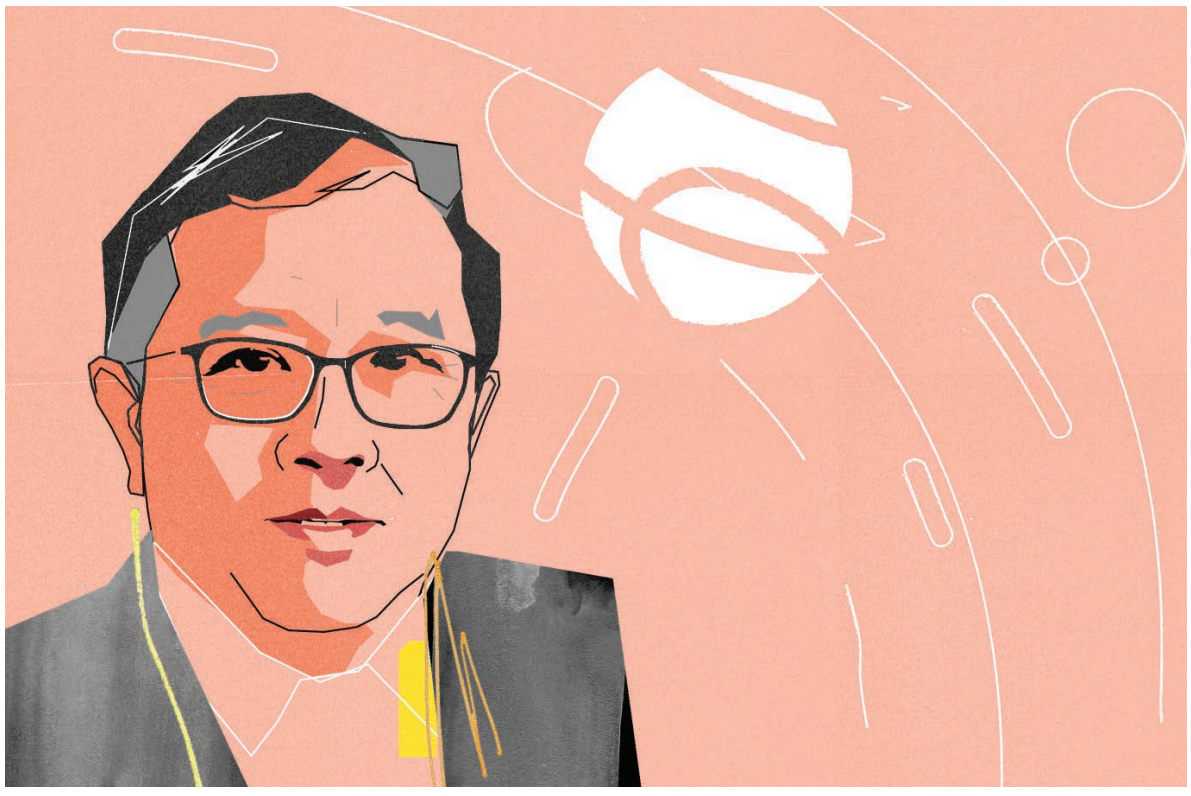

WUJI UPWARD BOUND

\section{The country's top space-science official aims high with bold research missions.}

\section{BY CELESTE BIEVER}

A fleet of model spacecraft decorates Wu Ji's office, including the Chang'e 3 lander and its Yutu rover that made up China's first mission to explore the Moon's surface. That expedition in December 2013 captivated the world and signalled China's vast ambitions in space. But for Wu, who has been director-general of China's National Space Science Center (NSSC) in Beijing since 2003, a much bigger turning point came almost three years earlier.

On 11 January 2011, he learned that his centre, which is a division of the Chinese Academy of Sciences (CAS), had won funding for a flotilla of spacecraft dedicated to scientific discovery. Up to that point, say Wu and others, almost all of China's space missions had been geared primarily towards advancing national prestige or demonstrating technological prowess.

The 2011 announcement marked the culmination of more than a decade of research, persuasion and international collaboration, mainly on the part of $\mathrm{Wu}-$ and the start of a new era in Chinese science. "China has changed direction, and he has been the most important player," says Roger-Maurice Bonnet, former director of science at the European Space Agency, who is an adviser to the NSSC and a scientist at the non-profit International Space Science Institute in Bern.

Two of the NSSC missions have launched. One of them is Wukong, a space telescope hunting for signs of dark matter, which is thought to make up $85 \%$ of the matter in the Universe. "The data is coming down every day," says Wu. The mission's team may have an announcement by the end of the year that could "be a mark in science history", he says.

Next up in 2016 will be the world's first space-based experiment to probe the phenomenon of quantum entanglement, and the Hard X-ray Modulation Telescope (HXMT), which will survey a broad region of the sky with greater sensitivity at high energies than other wide-field telescopes.

The funding for these missions has totalled about 3 billion yuan (US $\$ 455$ million) since 2011, and Wu succeeded in winning the cash by persuading the top brass at the CAS and China's central government that his agency's proposals for basic space-science missions would deliver breakthroughs. That message resonates with the government's push to invest more in fundamental research.

In person, $\mathrm{Wu}$ is hyper-focused on making clear that Chinese research must earn acclaim for its intrinsic value, not just because it is a first for the nation. "There is no Chinese space science," he says. "Only science."

Funding for space research remains a concern because it is allocated in five-year cycles, making it difficult for research communities to mature. But he is confident that space science will gain a steadier source of support - especially if the latest satellites deliver the goods - because both Chinese politicians and the general public increasingly recognize the importance of scientific discovery. "We are a big nation," he says. "For human civilization, we should make contributions." -

\section{NANCYIP}

MAKING CONNECTIONS. Nancy Ip has been building bridges for much of her career. Born in Hong Kong, she found her calling in science during a graduate degree studying neurotransmitters at Harvard Medical School in Boston, Massachusetts. Then she crossed into the biotechnology industry, where she explored the neurotrophic factors that support neuron survival and growth. She took all that expertise back to her native land in 1993, joining the Hong Kong University of Science and Technology (HKUST) when it was just two years old.

"It was considered bold" to move to a place not known for its research, she says, but she wanted to contribute to the region. And since then, she's worked to bolster science and biotechnology there through her research and leadership. "I sleep very little," says Ip, who puts in a 12-hour-plus work day and gives credit to her support team. "Time flies when you are doing things that you enjoy." A lot of that time is spent with her large research group, which spans basic neural biology and translational science for neurological disorders

Ip has witnessed huge transformations since her return: Hong Kong transferred from British to Chinese control in 1997, and she's seen mainland China's science scene boom. And Ip is now building bridges to the mainland, where she hopes to further clinical research by accessing large populations of people with conditions such as Alzheimer's disease; training people with expertise in both clinical medicine and research; and playing a leading part in a major brain project being developed in China. "I teach my students, sometimes you don't know where research will take you." - BY HELEN PEARSON

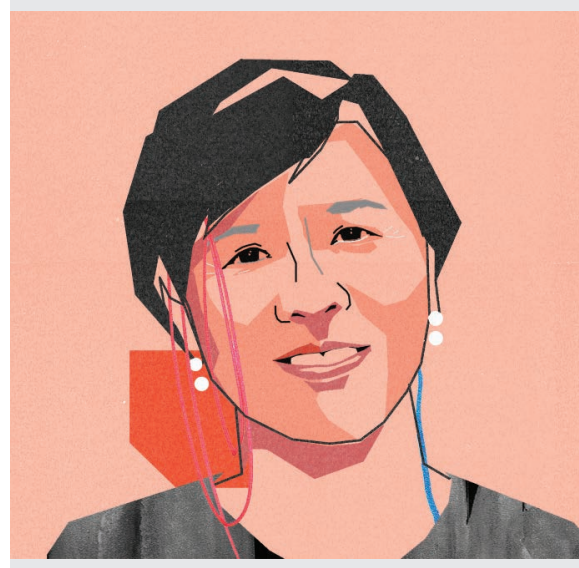




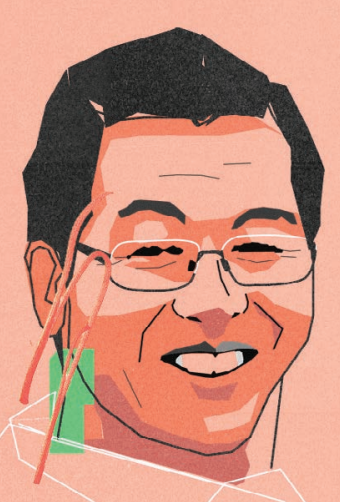

\section{CUIWEICHENG}

DEEP DIVER. Cui Weicheng will never forget the dive of his life: riding inside China's Jiaolong submersible as it reached a depth of more than 7,000 metres in the Pacific's Mariana Trench 4 years ago. "It's rather desolate down there - but strangely beautiful," says Cui, who led the submersible project.

Thanks to Jiaolong, China is now one of only a handful of nations that have the capability to explore the deep sea. Jiaolong, which is named after a mythical sea dragon, can travel deeper than any other manned research submersible currently in operation - allowing the country to reach more than $99.8 \%$ of the ocean floor.

"This symbolizes China's increasing ambition — and leadership - in deep-sea research," says Jian Lin, a marine geophysicist at the Woods Hole Oceanographic Institution in Massachusetts. Until recently, China's ocean research focused largely on coastal and offshore waters. But, driven by a growing desire for resources and a stronger position in international disputes over marine regions, it is stepping up its support for scientific programmes in the deep ocean.

Now at Shanghai Ocean University, Cui is aiming to reach the deepest place on Earth - the Challenger Deep valley at the bottom of the Mariana Trench, 11,000 metres down. To achieve this goal, he is leading an effort to build a more-pressure-resistant three-person submersible called Rainbow Fish at a cost of US\$61 million.

When it is completed in 2020, the vessel will be available for use by scientists around the world, says Cui. "The oceans belong to humanity rather than individual nations." BY JANE QIU
NIENGYAN CRYSTAL

\section{A structural biologist unlocks some problem proteins.}

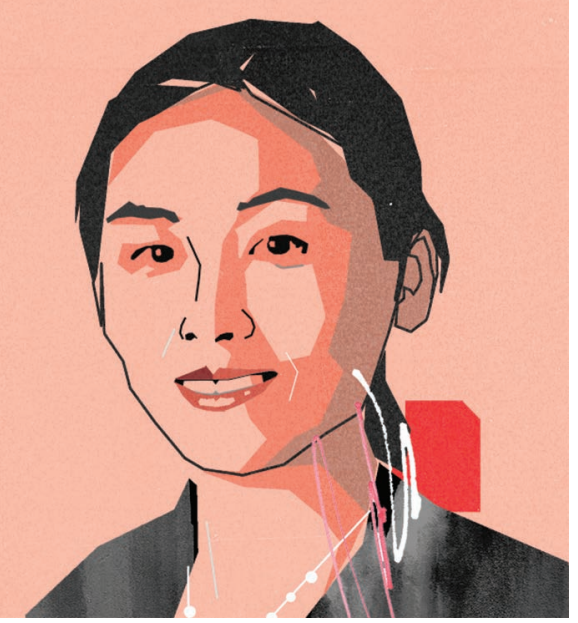

\section{BY ERIKA CHECK HAYDEN}

A s a girl, Nieng Yan read a classic sixteenth-century Chinese novel featuring a monkey that can transform into other animals. Yan wondered what it would be like to change herself: "If you could shrink yourself into the size of a molecule or a protein, that would be a totally different world," she recalls thinking. Now, as a leading structural biologist, Yan inhabits that world every day, investigating the way proteins work at the level of atoms. "It was almost destined that I would became a structural biologist," she says.

Yan did graduate and postdoctoral research at Princeton University, New Jersey, then set up her own laboratory at Tsinghua University in Beijing in 2007 when she was 30 years old, becoming one of the youngest-ever female professors in China. She focused on determining the structures of proteins embedded in cells' plasma membranes, which are notoriously difficult to solve.

One of her targets was the human glucose transporter GLUT1 - a protein that is essential for supplying energy to cells. Many labs had tried to determine its structure, but the protein had defied their efforts, in part because it readily changes its shape. Yan used a series of tricks to restrict its troublesome movements and finally managed to make crystals and solve its structure in 2014.

"People tried to crystallize GLUT1 for more than 50 years, and all of a sudden, bingo - she hit it," says biochemist Ronald Kaback at the University of California, Los Angeles.

Yan's hits have kept on coming, with a series of high-profile structures. She stays up most nights until 2 or 3 a.m. and skips morning meetings to maximize her time in the lab. Yan has also become a high-profile advocate for better conditions for women and young scientists.

She is excited about using the latest technologies, such as cryo-electron microscopy, which for the first time is allowing researchers to study proteins in fine detail in their native environments, rather than as purified crystals. Yan says that one of the benefits of working in China is she never has to worry about funding and sees a bright future for structural biology there. "The sky's the limit," she says.

\section{WANG YIFANG | PARTICLEPOWER}

\section{A leading high-energy physicist hopes to smash records with a giant collider.}

\section{BY ELIZABETH GIBNEY}

$\mathrm{W}$ ang Yifang has a plan to catapult China to the forefront of particle-physics research. The director of the Beijing-based Institute of High Energy Physics (IHEP) wants to build a 50-100-kilometre circular particle collider to succeed the 27-km-circumference Large Hadron Collider (LHC) at CERN, the particle-physics laboratory near Geneva, Switzerland.

The plan is bold, particularly for a country whose biggest existing collider ring is less than 250 metres long. Wang's plan entails building two machines: the first would explore the Higgs 


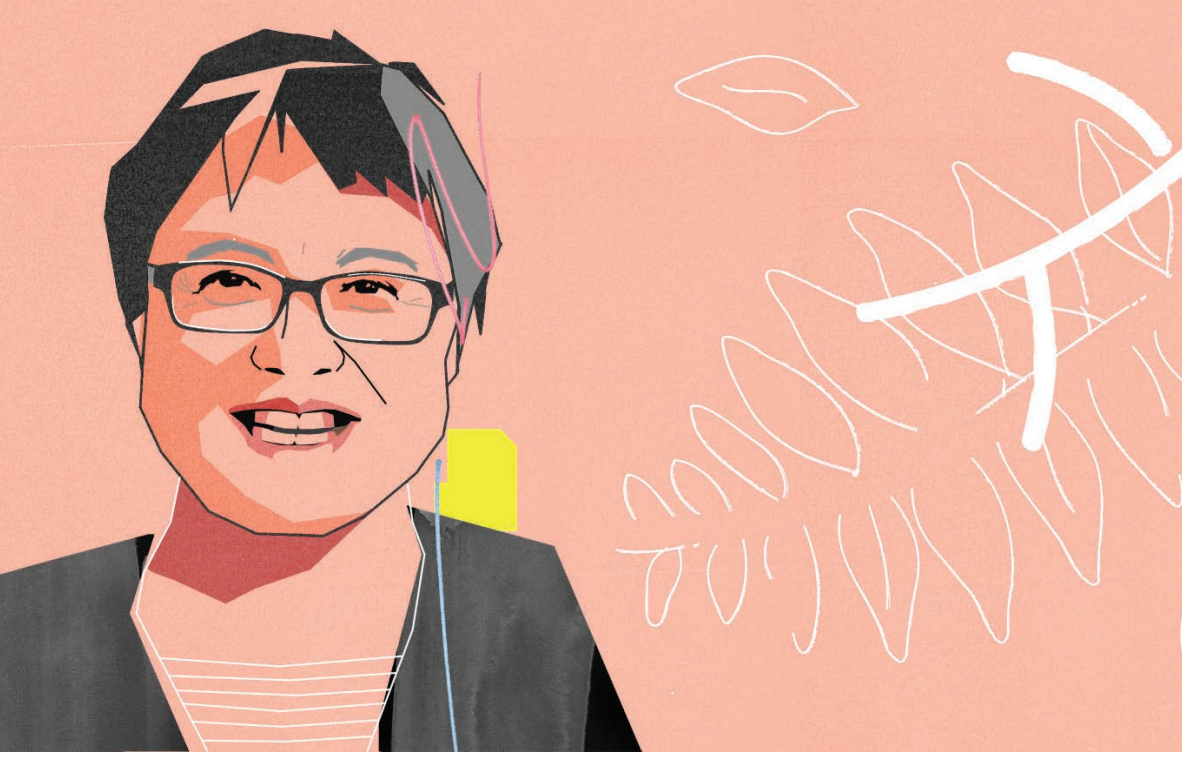

\section{CAIXIA GAO ICROP ENGINEER}

\section{A gene-editing specialist seeks to make her mark by improving key agricultural plants.}

\section{BY HEIDI LEDFORD}

$\mathrm{P}$ lant biologist Caixia Gao was initially reluctant to take up gene editing using CRISPR-Cas9 - the technique that is sweeping through biology laboratories around the world. Her lab had already made mutations in 82 genes using an older technology, and the thought of switching to something new was daunting. "At first I felt some resistance," Gao says. "And then we decided: well anyway, we have to try."

After a year of frenzied work, her lab at the Chinese Academy of Sciences' Institute of Genetics and Developmental Biology in Beijing became the first to use the revolutionarily simple gene-editing technique in crops, specifically wheat and rice $(Q$. Shan et al. Nature Biotechnol. 31, 686-688; 2013). "If there's any lesson we learn in genome engineering, it's that you have to be very flexible and adapt to technology that changes every day," says Daniel Voytas, a plant biologist at the University of Minnesota in Saint Paul. "Caixia has that ability to adapt."

She has been doing that for her whole career. Gao went to university planning to go into medicine, but was redirected to agriculture. "Not my interest at all," she says. "But my thinking is always: as long as I am in this position, I will do my best." After a PhD in grassland ecology, Gao switched again by taking up plant genetic engineering at the seed company DLF in Roskilde, Denmark.

Gao had to develop methods for inserting foreign genes into grass, which was frustrating work, says Klaus Nielsen, research director at DLF. Many grasses are difficult to engineer, and each species - or even genetic variants within a species - may require its own special mix of growth conditions. Gao is famously cheerful, but there were days when Nielsen could tell that she was seething.

Even so, she pressed on. "Eventually, she could look in the microscope and see things no one else could see," Nielsen says. "She was cracking the nut every time."

During Gao's 12 years at DLF, she cracked that nut again and again - by genetically altering several traits, including the times when key grass species flower. But European suspicion of genetically engineered crops left her with little hope that her work would leave the lab. "It was so difficult to bring a crop to the market - in the end, the work cannot inspire you any more," she says. That issue, plus a desire to return with her children to her mother language and culture, sent her back to China.

In Beijing, Gao tackled genetic engineering in wheat, a crop that is legendary for its difficultly to work with, in part because many strains have six copies of the genome. Soon she was considered one of the best in the world at engineering wheat, says Voytas.

Gao is happy with her decision to return to China, where funding for agricultural research is a higher priority than it is in Europe, she says. The government has approved some crops developed with early genetic-engineering techniques, but such approvals have slowed, and China has yet to decide how it will regulate gene-edited crops.

Still, Gao is hopeful that some of her creations will reach the market. Meanwhile, a disease-resistant wheat engineered in her lab is being further developed by a company in the United States. Ever the optimist, Gao refuses to accept public fears about genetically modified organisms (GMOs). "If I meet some people in the street and I ask, they will say they don't want GMO at all," she says. "And I stop there and educate them. They are so surprised." boson starting in around 2028; its follow-up would occupy the same tunnel and smash particles with up to seven times the energy of the LHC.

China will have to compete against CERN, which also wants to host a post-LHC machine. Although China remains the underdog, Wang's scheme has captured increasing support, says Nima Arkani-Hamed, a theoretical physicist at the Institute for Advanced Study in Princeton, New Jersey, whom Wang brought on board to lead IHEP's Centre for Future High Energy Physics in 2013. "Now it's not purely fantasy. It has a chance of really happening," he says.

Wang says that he only dared to pitch the project because of the success of China's Daya Bay Reactor Neutrino Experiment. He led that multinational collaboration, which beat international rivals in 2012 by measuring a parameter that governs transformations in the ghostly particles.

At more than 250 times the price of Daya Bay, the Chinese mega-collider will be a harder sell. China's government has yet to say whether it will foot the facility's estimated US\$6-billion bill. Brian Foster, a physicist at the University of Oxford, UK, says that Wang has proved he can get major projects off the ground and bring in international support.

And one of his best attributes is persistence, says Shing-Tung Yau, a mathematician at Harvard University in Cambridge, Massachusetts. "He usually succeeds."

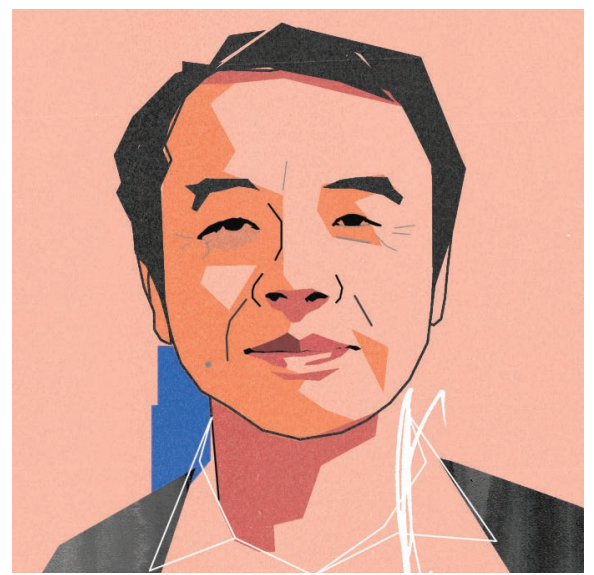




\section{QIAOMEIFU / GENOME HISTORIAN}

\section{A geneticist uses ancient human remains to rewrite Asia's prehistory.}

\section{BY EWEN CALLAWAY}

$\mathrm{Q}$ iaomei Fu says that she was nervous when she arrived at Germany's Max Planck Institute for Evolutionary Anthropology to pursue a PhD on ancient-human genomics, in 2009. Her master's research in China had focused on the diets of early farmers, and she had no experience with ancient DNA, or even genetics. But Fu jumped headfirst into her new field and "turned out to be one of the most amazing students we've ever had", says Svante Pääbo, a geneticist at the hub for ancient genomics in Leipzig.

With a trio of Nature papers published in the past 20 months, Fu has helped to redraft the history of Europe's earliest modern humans. She returned to China in January to lead an ancient-DNA lab at the Institute of Vertebrate Paleontology and Paleoanthropology (IVPP) in Beijing, where she is set to bring the same upheaval to Asia's ancient past.

She joined Pääbo's team just as it was putting the finishing touches to a draft Neanderthal genome. "It was really high pressure. There were a lot of really interesting things, and a lot of scary things for me," says Fu. "I came there at really the right time." Fu learned how to harvest the scant DNA in ancient bones and quickly picked up evolutionary genetics, bioinformatics and computer programming to analyse the data that she was generating.

Her focus soon turned to the early modern humans who settled Eurasia after leaving Africa, and Fu began collecting and analysing their bones and teeth. She has sequenced the oldest Homo sapiens DNA on record: from a 45,000-year-old thigh bone from Siberia and a 40,000-year-old jawbone from a man who had a Neanderthal ancestor in the previous 4-6 generations. Her efforts - culminating in a study of 51 individuals who lived between 14,000 and 37,000 years ago - have shown that Ice Age Europe was more tumultuous than many had thought, with waves of migrants moving in and around the continent and contributing to the ancestry of contemporary Europeans.

Asia's early history may have been even more dramatic than that, because several groups of archaic humans probably coexisted with modern humans, says María Martinón-Torres, a palaeoanthropologist at University College London who works in China. Fu will turn her attention to the first Homo sapiens to settle Asia, who might have arrived more than 100,000 years ago. She also hopes to study Asian history as recent as a few thousand years ago — the IVPP has a vast collection of ancient human bones that have yet to be sampled for DNA.

$\mathrm{Fu}$ is often asked why she returned to China instead of staying in the West. "I'm curious what happened in China and east Asia," she responds, "I think it was time to come back." .

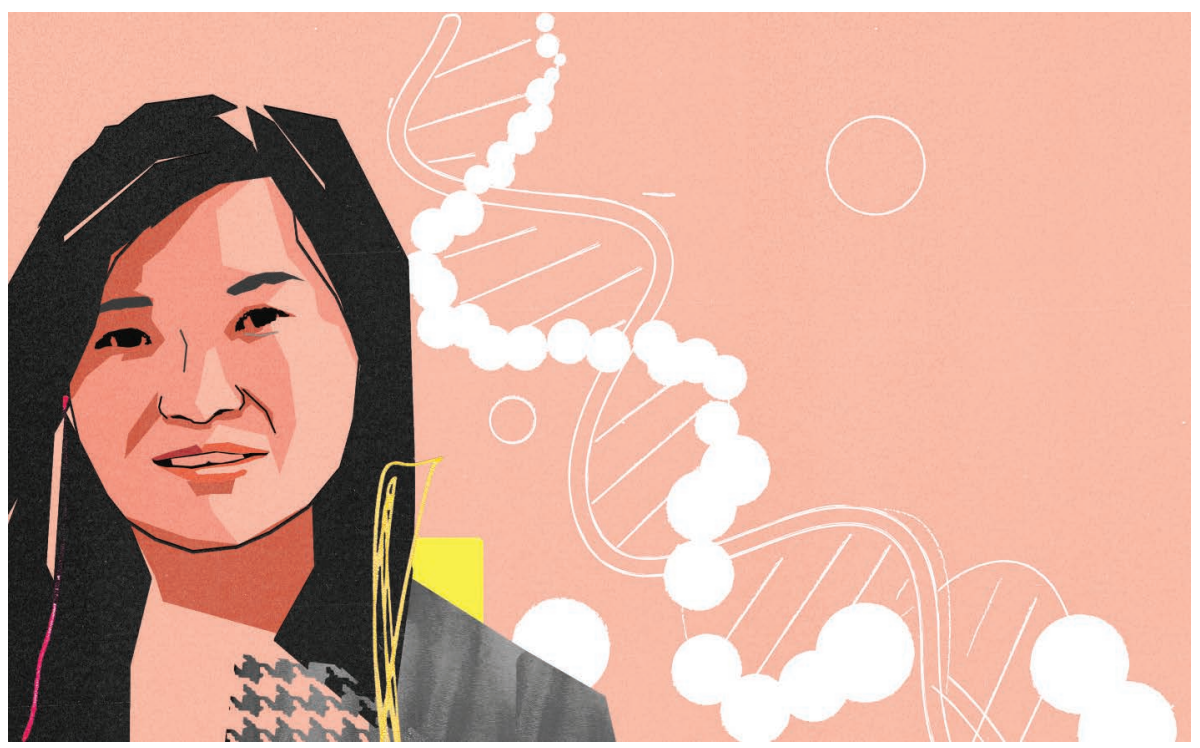

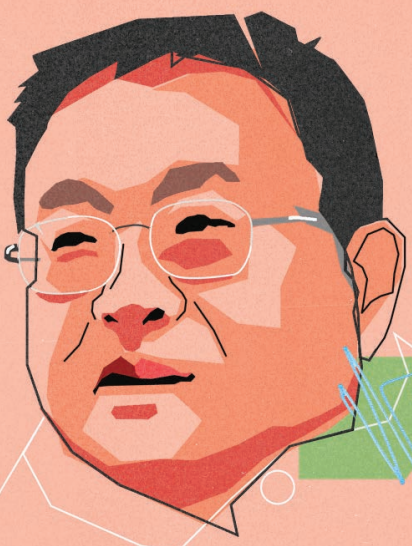

QINWEIJA

POLAR EXPLORER. When Qin Weijia first visited Antarctica in 1989, he fell in love with this terra incognita. "It's a mysterious continent, full of unknowns and extremes," says Qin, who is the executive deputy director of the Chinese Arctic and Antarctic Administration in Beijing.

Since then, he has been to the frozen continent half a dozen times, including as the 1996 leader of China's first inland traverse towards Dome A - the highest point and one of the least studied regions in Antarctica. That was the first of a series of expeditions, which culminated in the construction of China's Kunlun station on Dome A in 2009.

The country is a relative late comer to polar research, but the Chinese government is investing heavily in both the Arctic and Antarctic, driven by the desire for natural resources and for a bigger say in international discussions about the regions.

Last December, an international team flew ice-penetrating radar and other sensors on China's first fixed-wing aircraft on the continent as it traversed back and forth across thousands of square kilometres over Princess Elizabeth Land in Eastern Antarctica to map features under the ice. "It was the first survey of its kind in a part of Antarctica we know very little about," says Martin Siegert, a glaciologist at Imperial College London. "The results are spectacular."

The team discovered the longest canyon on Earth and one of the largest areas of melt under the ice sheet, says Qin, who led the 2015-16 expedition.

Looking forward, he hopes that China will be able to retrieve the oldest ice on the planet from Dome A, which will help to uncover the history of the Antarctic ice sheets and how they have changed. "Only then," says Qin, "can we predict how they will respond to a changing climate". — BY JANE QIU 


\section{CHENJNING POLLUTION PATROL}

\section{The top environment official tackles deadly air.}

\section{BY JEFF TOLLEFSON}

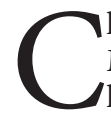

hen Jining has a tough job. As head of the Ministry of Environmental Protection, he is responsible for cleaning up the pollution that blankets China's cities, contaminates its drinking water and laces its croplands with toxic compounds. Although he faces formidable odds in one of the most polluted countries in the world, Chen has gained the confidence of many environmentalists and fellow scientists in his first 15 months on the job by stepping up efforts to root out corruption and ensure that local officials and companies are following rules.

"Local officials are being held more strictly accountable on the environment quality," says Li Yan, who is deputy programme director for Greenpeace East Asia and works in Beijing. And because Chen's efforts to reduce air pollution often reduce carbon emissions as well, Li says that the benefits of these reforms extend well beyond the affected areas. "This has massive global implications."

After earning his doctorate at Imperial College London in 1993, Chen worked his

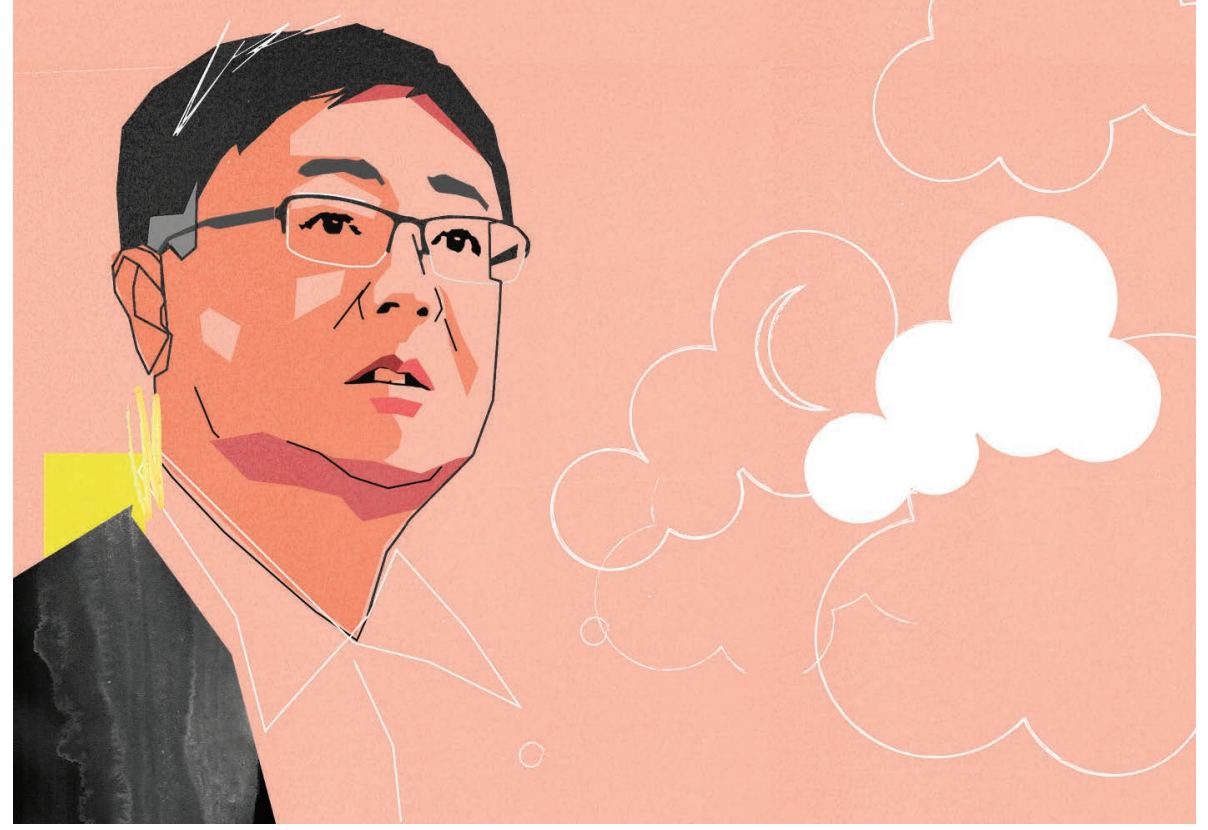

way through the ranks of Chinese academia to become president of Tsinghua University in Beijing in 2012. Now it looks as though he could become the most powerful Chinese environment minister in modern times.

His appointment as head of the environment ministry coincided with a new law that expanded the agency's regulatory powers. $\mathrm{He}$ pushed for additional authority to investigate and prosecute polluters, and in May that request was granted. This makes it easier for Chen to intervene when local officials fail to implement many of the government's policies on pollution and development.

In addition to cracking down on pollution, Chen's ministry has worked to strengthen environmental assessments and has boosted transparency by posting more environmental monitoring data on its website, including airquality readings, as well as information about its enforcement activities.

Chen has often shunned contact with the media, but fellow scientists say that he has been willing to listen to and collaborate with outside scientists and international experts on issues such as air quality.

"He once said that the history of China's environmental protection is a history of international cooperation on environment and development," says Lailai Li, who heads the Beijing office of the World Resources Institute, on whose board Chen once sat.

The minister still faces huge challenges, however. Citizens are increasingly demanding that the government clean up the environment, but China's rapid industrial rise has created a backlog of problems. Cleaning up the air in major cities may be the easiest task facing Chen; regulators are only beginning to grasp the extent of the water and soil contamination.

And government authorities continue to approve industrial projects, even when the environmental costs are all too clear, says Dasheng Liu, an environmental engineer and research fellow at the Shandong Institute of Environmental Science in Jinan. "He has more power than before," Liu says, but he also faces "more arduous and heavy responsibilities."

Additional reporting by David Cyranoski.

\section{CHAOYANGLU}

QUANTUM WIZARD. When Chaoyang Lu was at school in a tiny village in Zhejiang province, he fell in love with physics. "You could figure out how everything works by a few simple equations," he says.

Now Lu is a rising star in China's push to master quantum information technology — which could eventually lead to powerful new types of computing and secure communications. The 33-year-old, a physicist at the University of Science and Technology of China in Hefei, is noted for his work with 'entanglement', in which the quantum states of different particles are linked regardless of how far apart they are. He has entangled eight photons at once - a world record - and has submitted work using ten. Those achievements led Anton Zeilinger, a quantum physicist at the Vienna Center for Quantum Science and Technology, to call Lu a "wizard of entangled photons". He has also done groundbreaking work with his mentor, Pan Jian-Wei, in the related phenomenon of quantum teleportation, in which a quantum state is transported from one particle to another.

It was Pan who encouraged Lu to do his PhD work at the University of Cambridge, UK, and who convinced him to return to China with the promise that the government is investing heavily in quantum information technologies, and that bright young physicists could focus on research rather than funding. Lu's goal is to advance quantum entanglement enough to use it for computations. "It will be exciting to see, for the first time, a task where a quantum machine can do a better job than a classical one can," says Lu. B BY M. MITCHELL WALDROP

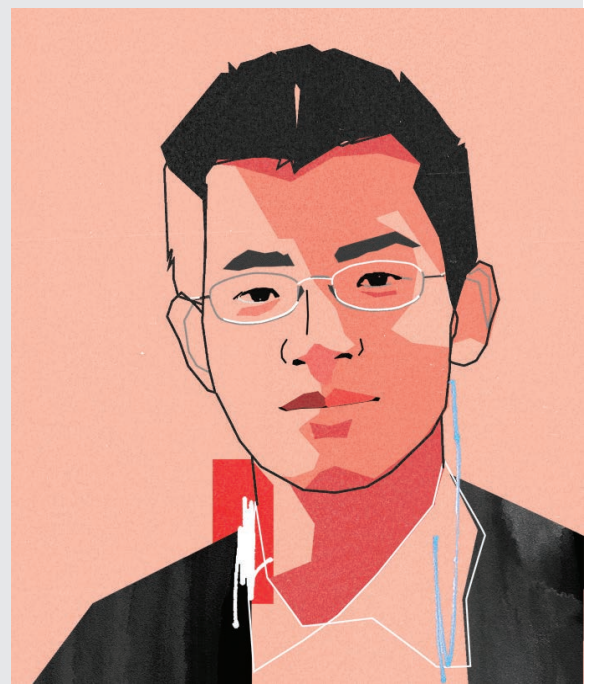

